How Can PhD Research

Contribute to the Global Health

\section{Research Agenda?}

\author{
Susan H. Walker, $\mathrm{PhD}$ (candidate), $\mathrm{MA}^{1}$ \\ Veronic Ouellette, $\mathrm{PhD}$ (student), MD, MSc, $\mathrm{CCFP}^{2}$ \\ Valéry Ridde, PhD, MSc, Dess ${ }^{3}$
}

\section{ABSTRACT}

We propose that $\mathrm{PhD}$ and post-doctoral researchers are a strong, untapped resource with the potential to make a real contribution to global health research (GHR). However, we raise some ethical, institutional and funding issues which either discourage new researchers from entering the field or diminish their capacity to contribute.

We offer a number of recommendations to Canadian academic and non-academic institutions and funders, and aim to generate discussion among them about how to overcome these constraints. We need changes in the way graduate research is organized and funded, to create opportunities to work collaboratively within established low- and middle-income country (LMIC)/Canadian research partnerships. We urge changes in the way institutions fund, recognize, value and support GHR, so established researchers are encouraged to develop long-term LMIC relationships and mentor new Canadian/LMIC researchers. We ask funders to reconsider additional GHR activities for support, including strategic training initiatives and dissemination of research results. We also encourage the development of alternative institutions that can provide training and mentoring opportunities.

GHR per se faces many challenges. If we address those that reduce our potential to contribute, we can become real partners in GHR, working towards equitable global health and solutions to priority health issues.

MeSH terms: Global health; world health; international cooperation; public health; education, public health professional; international educational exchange

La traduction du résumé se trouve à la fin de l'article.

1. Department of Anthropology, McMaster University, Hamilton, ON

2. Department of Health Care and Epidemiology, University of British Columbia, Vancouver, BC; Student Representative on the Board of the Canadian Coalition for Global Health Research

3. Faculté de médecine, Unité de santé internationale, Centre de recherche du CHUM, Université de Montréal, Montréal, QC

Correspondence: Susan H. Walker, Department of Anthropology, McMaster University, Chester New Hall Rm. 524, 1280 Main Street West, Hamilton, Ontario, Canada, L8S 4L9, Tel: 905-648-3373, E-mail: walkersh@mcmaster.ca

Acknowledgements: We are grateful for the encouragement and helpful comments of Erica Di Ruggiero (CIHR) and Vic Neufeld (McMaster University, CCGHR). We thank all participants and organizers of the 2004 CCGHR Summer Institute (Resources and program at: http://www.ccghr.ca/ documents/Summerlnstitute2004.pdf).
T he Canadian research community has become increasingly committed to advancing global health equity and improving global health. ${ }^{1-3} \mathrm{New}$ alliances of researchers, policy-makers and funding organizations, such as the Canadian Coalition for Global Health Research (CCGHR), have come together to support research aimed at reducing the 10/90 gap - an unconscionable situation wherein only $10 \%$ of health research is aimed at diseases (such as TB, malaria, HIV/AIDS) that make up $90 \%$ of the global burden of disease, borne by the world's poorest people., ${ }^{4,5}$

Many Canadian doctoral and postdoctoral researchers, who are new members of the research community, support this growing effort and are asking, 'How can Canadian $\mathrm{PhD}$ research contribute to the global health research and action agenda? What can we add with our research? What stands in the way?'

Twenty-one 'new' global health researchers from Canada and various lowand middle- income countries (LMICs), who attended the CIHR-funded CCGHR 2004 Summer Institute, vigorously debated these questions. The participants included ten dyads of Canadian/LMIC $\mathrm{PhD}$, post-doctoral and other researchers with less than five years experience, who came together for five days of mutual learning, mentored project planning and problem-solving. Their workshop deliberations and a subsequent brainstorming session revealed the strengths and untapped potential of doctoral and post-doctoral research as a resource for global health. However, participants also raised some ethical, institutional and funding issues which either discourage new researchers from entering the field or diminish their potential to contribute. While LMIC and Canadian researchers share some of the same challenges, those faced by researchers from LMICs are truly daunting ${ }^{6-8}$ and need urgent attention. Their voices are included in this commentary, but our LMIC colleagues need further opportunities to raise their particular issues and indicate how northern researchers, institutions and donor agencies could support their goals. Here, we offer a Canadian perspective and propose a number of recommendations for Canadian funders and institutions. We seek broader thinking and aim to stimulate discussion among them. 


\section{THE POTENTIAL FOR PHD RESEARCH TO CONTRIBUTE TO GLOBAL HEALTH}

Today's Canadian graduate researchers $d o$ have the potential to make a unique and valuable contribution to global health. As individuals, we come to our careers with attitudes and motivations shaped by a globalizing world that did not exist a generation ago, and influenced by a remarkable mix of experiences, education and travel. These have formed our values, our view of the world and our place in it. As researchers from a wide variety of disciplines, we are keenly aware of how global issues affect health and feel an ethical imperative to respond to the research needs and priorities of LMICs. We approach our research with ideals of social justice, health as a human right, a sensitivity to the past failings of development, and a desire to reduce global disparities. ${ }^{9}$ We want our research to be more than the pursuit of new knowledge - it must respond to, and be translated into, solutions that address real world problems.

Our education has given us new tools and paradigms to think about health research for development; we imagine new possibilities and bring fresh questions to ethical and methodological issues. Unconstrained by the pressures of gaining tenure, we can bring creative approaches from outside the academic system and give concentrated time and attention to indepth inquiry, reading, research problems, data analysis and interpretation - a luxury envied by more established researchers whose time is often consumed and diverted by many other responsibilities and pressures.

In spite of these positive attitudes, motivations and skills, our expertise is underutilized in the service of improving global health. Why is this? What stands in the way and needs to change so we can become real partners in global health research (GHR)?

\section{CHALLENGES AND}

RECOMMENDATIONS

1. First, there is a need to overcome several constraints inherent in the organization and delivery of graduate research per se, particularly its relative- ly short timeframe, its inadequate funding, its solitary nature and its potentially narrow, discipline-specific focus. Each can affect the quality and effectiveness of our work and partnerships.

Research on complex global health issues requires collaboration among a variety of constituencies, such as communities, non-governmental organizations (NGOs), governments, and universities, and must transcend disciplinary and contextual boundaries to be successful. ${ }^{10}$ Such research must be founded on strong, trusting Canadian/LMIC relationships, which take considerable time and effort to build and maintain but promote research and a research process that is more relevant, useful and ethical. ${ }^{11}$ Because of academic timeframes and lack of opportunity, many graduate researchers are unable to develop these essential trust relationships; the result can be undesirable and potentially harmful ${ }^{12}$ 'helicopter', decontextualized or curiosity-driven research. As well, most doctoral programs do not provide opportunities for collaboration and graduate students work alone in intellectual silos, without the 'interdisciplinarity' espoused by their universities.

- To address these constraints, we suggest universities or alternative institutions develop and provide innovative opportunities that would enable Canadian and LMIC doctoral researchers to work within already established global health research partnership programs. Graduate research could then be informed, enriched and guided by local needs and contexts; be more respectful of, and respected by, those with whom we work; be more open to mentoring opportunities and the creative effects of working within research teams. Our work would then be better able to contribute to priority global health problems.

Creative programming and funding for LMIC partnership research could, for example, generate opportunities for doctoral students from Canada and LMICs to work on collaborative research projects. This would respond to LMIC researchers' concerns about lack of academic resources, training opportunities, funding (many scholarships are for Canadian citizens only), and provide opportunities for research on LMIC priorities rather than Canadian issues, which are better funded. Such initiatives could build capacity in both countries and strengthen partnerships for the long term. LMIC researchers would be better prepared to build research programs relevant to their countries' needs after graduation.

2. Such collaborative opportunities require changes in funding and the way institutions recognize, value and support GHR. ${ }^{13}$

- To ensure that GHR becomes recognized as an important academic stream in Canada, senior academics - particularly deans and chairs - need to provide creative leadership and an environment that encourages and supports GHR.

- To encourage Canadian faculty and new graduate researchers to pursue careers in GHR, universities need to give greater recognition and reward to non-traditional activities for tenure and promotion. Faculty members have little incentive to engage in GHR - with its time-consuming activities like partnership building, mentoring, long-term applied and action research in LMICs - when publishing, classroom teaching and conventional research are better rewarded.

- Established researchers need longerterm funding and institutional support to develop LMIC research collaborations, make badly needed curriculum revisions and nurture new researchers. As institutional attitudes and culture slowly change, researchers could be helped to make better use of existing structures.

- Senior researchers who head up global health research programs and projects should include positions for doctoral and post-doctoral students, both Canadian and LMIC, in their funding proposals, to provide learning, supervision and capacity-building opportunities. 
3. We also urge funders to reconsider the kinds of GHR activities they will support. For example:

- Graduate and post-graduate training in global health needs more funding through strategic training programs and personnel awards. For example, only about $1 \%$ of CIHR's grants in 2000-2001 were for this purpose [E. Di Ruggiero, Personal communication, February 7, 2005], not including trainee support provided through global health-oriented operating grants. For the October 2004 post-doctoral fellowship open competition, CIHR received 469 applications and provided only 82 awards - just 9 related to public health and 1 to global health. Clearly, training for GHR needs a higher profile.

- Graduate involvement in GHR could be encouraged by funding support for the added costs involved with travel, living expenses in the field, extra communication and translation costs and follow-up responsibilities.

- Canadian graduates need funding to support external members from LMICs on our dissertation committees, ${ }^{14}$ to ensure the relevance of our proposals, validate our interpretations and increase the potential for knowledge sharing/utilization.

- Funding strategies should support dissemination of our research results so they are meaningful and useful to our partners in LMICs. More knowledge transfer initiatives like IDRC's Research Matters (http://www.researchmatters.net) are needed so our research can inform policies, programs and practices (see for example ref. 15), and enable the advocacy work that is ethically required. ${ }^{16}$ In the field, we raise people's expectations that they will benefit simply by our presence; they give us data in good faith and expect something back. Instead, it is we who benefit, with our degrees and publications.

- Coalitions, such as CCGHR, the University of Saskatchewan's Global Health Research Interest Group, $U B C$ 's Centre for International Health and others, need support to continue their advocacy work, GHR development efforts and information sharing/learning programs.

4. A key issue in Canada is the relative lack of alternative institutions where GHR can be nurtured and conducted. Universities, even with support from research funding agencies, may be unable to address the challenges we have outlined. We urge the development of such alternative institutions (e.g., policy research think tanks and NGOs) which would build capacity for GHR and provide opportunities for training and mentoring of global health researchers.

\section{CONCLUSIONS}

Global health research inherently faces many challenges and constraints, including high costs, inadequate funding, scarce and unequal access to resources, competing priorities, cultural differences, communication difficulties, the need to build and work in partnerships, under-developed research infrastructure, distance, isolation, weak LMIC/Canadian academic institutional support and training/mentoring, to name a few. We have discussed some of these as seen by 'new' graduate researchers and make a plea for changes in academic program structure, institutional support and funding that would enable us to contribute better to the GHR agenda. We believe existing challenges and constraints can be overcome, and that addressing them could benefit the entire research community.
Certainly, there is a growing acknowledgement that Canadian researchers have a distinct role in addressing the research gap in global health and have a strong record of excellence in public health research. There is also great commitment and energy among many established Canadian global health researchers to build capacity and leadership in 'new' researchers. There is little doubt that $\mathrm{PhD}$ and post-doctoral researchers are a strong, untapped resource with the potential to make a real contribution with their work. Let us push for the changes that will enable Canadian researchers, both new and established, to work together for equitable global health and the realization of the Millennium Development Goals. ${ }^{17}$

\section{REFERENCES}

1. Reckart ML, Reckart JT, Patrick DM, Brunham RC. International health: Five reasons why Canadians should get involved. Can J Public Health 2005;94(4):258-59.

2. Neufeld V, MacLeod S, Tugwell P, Zakus D, Zarowsky C. The rich-poor gap in global health research: Challenges for Canada. CMAJ 2001;164(8):1158-59.

3. Labonte R, Schrecker T, Sanders D, Meeus W. Fatal Indifference: The G8, Africa and Global Health. Ottawa, ON: IDRC-UTC Press, 2004.

4. Commission on Health Research for Development. Health Research: Essential Link to Equity in Development. New York, NY: Oxford University Press, 1990.

5. Global Forum for Health Research. The 10/90 report on health research 2003-2004. Geneva, Switzerland: Global Forum for Health Research, www.globalforumhealth.org, 2004: 282.

6. Raja AJ, Singer PA. Transatlantic divide in publication of content relevant to developing countries. BMJ 2004;329:1429-30.

\section{RÉSUMÉ}

...continues

Dans ce commentaire, nous avançons que les chercheurs postdoctoraux et les doctorants disposent d'un potentiel important pour contribuer de manière significative à la recherche en santé mondiale (RSM). Cependant, nous relevons un certain nombre de contraintes éthiques, institutionnelles et financières qui peuvent décourager ou limiter la contribution de ces nouveaux chercheurs.

Nous proposons certaines recommandations aux établissements de recherche canadiens, universitaires ou non, ainsi qu'aux bailleurs de fonds, et nous souhaitons susciter des discussions concernant la manière d'agir afin de limiter ces contraintes. Nous suggérons des changements dans la manière dont les recherches étudiantes sont entreprises et financées, afin de créer des occasions de travail concerté a l'intérieur de partenariats déjà établis entre le Canada et les pays à revenus faibles ou moyens (PRFM). Nous réclamons des changements dans la manière dont les établissements financent, reconnaissent et valorisent la RSM de sorte que les chercheurs établis soient encouragés à développer des relations à long terme avec les PRFM et à agir comme mentors pour les nouveaux chercheurs du Canada et de ces pays. Nous demandons aux bailleurs de fonds d'envisager le financement d'aspects particulièrement difficiles de formation et de diffusion des résultats localement dans le contexte de la RSM. Nous encourageons également la mise en place de nouvelles structures pouvant organiser des formations et offrir du mentorat.

La recherche en santé mondiale fait face à de multiples défis. Mais si nous relevons ceux qui sont défavorables à notre contribution, nous pouvons devenir de réels partenaires de la RSM dans le but d'améliorer l'équité en santé et de trouver des solutions aux problèmes de santé prioritaires. 
7. Hyder AA, Tasleem A, Qayyum A. Capacity development for health research in Pakistan: The effects of doctoral training. Health Policy Plan 2003;18(3):338

8. Ramsay S. African health researchers unite. Lancet 2002;360(9346):1665-66.

9. Farmer P. Pathologies of Power: Health, Human Rights, and the New War on the Poor. Berkeley, CA: University of California Press, 2003.

10. Johnson NA, Higgenbotham N, Briceño-León R. Best practice and future innovations in applying social science to advancing the health of populations. In: Higgenbotham N, Briceño-León R, Johnson N (Eds.), Applying Health Social Science: Best Practice in the Developing World. London, England: Zed Books, 2001;249-72.

11. Benatar $S$, Singer PA. A new look at international research ethics. BMJ 2000;321:824-26.

12. Hodge F, Weinmann S, Roubideaux Y. Recruitment of American Indians and Alaska Natives into clinical trials. Ann Epidemiol 2000;10(8 Supplement):S41-S48.

13. Baum FE, MacDougall C, Smith D. Participatory action research glossary. J Epidemiol Community Health; in press, 2005.

14. Ridde V. L'Université ouverte sur le monde, encore un petit effort! Au Fil des Événements. 2005. Available online at: http://www.scom.ulaval.ca/Au.fil.des.evenements/2005/02.10/courrier.html (Accessed on February 10, 2005).

15. Nitièma A, Ridde V, Girard JE. L'efficacité des politiques publiques de santé dans un pays de l'Afrique de l'Ouest : le cas du Burkina Faso. Int Pol Sci Rev 2003;24(2):237-56.

16. Nuffield Council on Bioethics. The ethics of research related to healthcare in developing countries. A follow-up discussion paper based on the workshop held in Cape Town, South Africa, 12 14th February 2004. London, 2005: 128.

17. Task Force on Health Systems Research. Informed choices for attaining the Millennium Development Goals: Towards an international cooperative agenda for health-systems research. Lancet 2004;364(9438):997-1003.

Received: May 19, 2005

Accepted: November 23, 2005

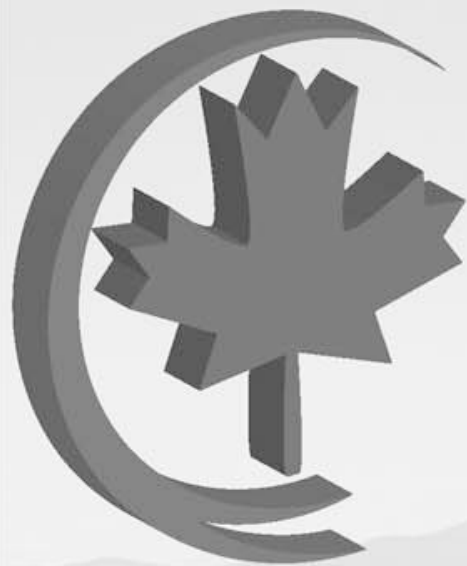

What Determines the Public's Health?

\section{Qu'est-ce qui détermine la santé du public?}

\section{Canadian Public Health Association 97 $7^{\text {th }}$ Annual Conference}

\section{$97^{\circledR}$ Conférence annuelle de I'Association canadienne de santé publique}

In partnership with:

- Carradian Institute for Health Information -

Canadian Population Health Initiative

- Canadian Institutes of Health Research -

Institute of Population and Public Health

- Public Health Agency of Canada

Organisée en collaboration avec :

- I'Initiative sur la santé de la population canadienne de

I'Institut canadien d'information sur la santé

- I'Institut de la santé publique et des populations des

Instituts de recherche en santé du Canada

- I'Agence de santé publique du Canada

In association with the

Public Health Association of British Columbia

En association avec l'Association

pour la santé publique de Colombie-Britannique

28-31 May 2006

du 28 au 31 mai 2006

The Fairmont Hotel Vancouver

Vancouver, BC/C.-B.

www.cpha.ca

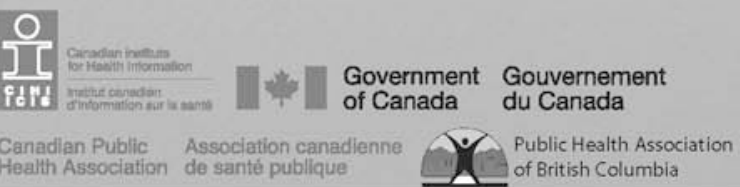

